\title{
PEMBERDAYAAN PAUD SEBAGAI UPAYA PENINGKATAN PERTUMBUHAN DAN PERKEMBANGAN ANAK USIA DINI
}

\author{
Kristiawati $^{1}$, dan E. Yunitasari ${ }^{2}$
}

\begin{abstract}
ABSTRAK
Pendidikan Anak Usia Dini (PAUD) merupakan lembaga pendidikan anak usia dini yang memiliki peran dalam pertumbuhan dan perkembangan anak. Guru PAUD memiliki peran untuk memberikan stimulasi dan memonitor perkembangan anak. Desa Petok, Kecamatan Mojo Kabupaten Kediri merupakan salah satu desa tempat praktik KKN mahasiswa Universitas Airlangga dan memiliki PAUD dengan guru yang belum pernah mendapatkan pelatihan deteksi perkembangan anak. Salah satu upaya mencegah terjadinya masalah perkembangan anak, maka dilakukan upaya pemberdayaan guru PAUD untuk mampu melakukan deteksi dini perkembangan anak. Beberapa program yang dilaksanakan adalah pelatihan, praktik dan pendampingan deteksi dini perkembangan. Hasil yang dicapai terjadi peningkatan pengetahuan, tingkat pengetahuan tentang pertumbuhan dan perkembangan anak meningkat untuk kategori baik menjadi $93,75 \%$, pengetahuan deteksi perkembangan untuk kategori baik sebesar $68,75 \%$ dan pengetahuan alat permainan edukatif pada kategori baik sebesar $62,5 \%$. Dukungan Kepala Desa sangat menunjang proses keberlanjutan program sebagai upaya preventif untuk mencegah masalah pertumbuhan dan perkembangan pada anak.
\end{abstract}

Kata kunci : anak usia dini, pertumbuhan anak, deteksi perkembangan, alat permainan edukatif, pemberdayaan

\begin{abstract}
Early Childhood Education (PAUD) is an educational institution in early childhood that has a role in the growth and development of children. PAUD teachers have a role to stimulate and monitor child development. Petok Village, Mojo Sub-District, Kediri Regency is one of the villages where the students of Airlangga University practice KKN and have PAUD that their teachers have never received training on child development detection. One effort to prevent child development problems. It is necessary to empower teachers of PAUD to be able to make early detection of child development. Some of the programs implemented are training, practice and mentoring early detection of development. The result is knowledge increase, knowledge level of growth and child development increased to good category to $93,75 \%$, knowledge of detection of development for good category equal to $68,75 \%$ and knowledge of educational game tool in good category equal to $62,5 \%$. Support of the village head strongly supports the sustainability of the program as a preventive effort to prevent growth and development problems in children.
\end{abstract}

Keywords: early childhood, child growth, developmental detection, educational game tools, empowerment

\section{PENDAHULUAN}

Anak usia dini adalah kelompok anak usia anak yang berada dalam proses pertumbuhan dan perkembangan yang unik (Suyanto, 2005). Hal ini disebabkan karena berada pada periode golden

\footnotetext{
${ }^{1}$ Staf Pengajar Fakultas Keperawatan Universitas Airlangga, kristiawati@fkp.unair.ac.id

${ }^{2}$ Staf Pengajar Fakultas Keperawatan Universitas Airlangga, esti-y@fkp.unair.ac.id
} 
age, yaitu masa yang tepat untuk memberi bekal kuat dan menggali potensi kecerdasan anak sebanyak-banyaknya (Hockenberry \& Wilson, 2012). Keberhasilan dalam menempuh tugas-tugas perkembangan masa kanak-kanak menjadi penentu bagi kehidupan anak pada saat dewasa.

Pendidikan Anak Usia Dini (PAUD) sebagai lembaga pendidikan anak usia dini memiliki peran dalam pertumbuhan dan perkembangan anak (Unicef, 2013). PAUD dalam penyelenggaraan pendidikan menitikberatkan pada dasar pada arah pertumbuhan dan perkembangan yang meliputi perkembangan moral dan agama, perkembangan fisik, perkembangan kognitif, perkembangan sosio emosional, dan perkembangan bahasa. Tujuan utama PAUD untuk membentuk anak Indonesia yang berkualitas yaitu anak yang tumbuh dan berkembang sesuai dengan tingkat perkembangannya. Selain itu tujuan penyerta adalah membantu menyiapkan anak mencapai kesiapan belajar di sekolah (Utami dkk,2013).

Salah satu faktor dalam penunjang keberhasilan pertumbuhan dan perkembangan anak adalah stimulasi. Stimulasi yang yang tepat dapat mengoptimalkan perkembangan anak (Kemenkes, 2010). Bermain merupakan salah satu upaya untuk merangsang pertumbuhan dan perkembangan anak dari segi fisik, sosio emosional dan kognitif (Hockenberry, 2009). Guru PAUD memiliki peran dan tugas untuk memberikan proses pembelajaran dan stimulasi sesuai dengan usia perkembangan anak (Utami, dkk, 2013).

Masalah pertumbuhan yang terjadi di masyarakat salah satunya adalah gangguan pemenuhan kebutuhan nutrisi, hal ini menyebabkan terjadinya obesitas, gizi kurang dan stunting. Presentase status gizi balita pendek/ stunting di Indonesia tahun 2013 adalah 37,2\%. Menurut WHO, prevalensi balita pendek menjadi maslah kesehatan masyarakat jika prevalensinya $20 \%$ atau lebih. Karena persentase balita pendek di Indonesia masih tinggi dan merupakan masalah kesehatan yang harus ditanggulangi (Kemenkes, 2016). Pemeriksaan tumbuh kembang di Jawa Timur pada tahun 2010 telah dilakukan pada 2.32.542 anak balita dan prasekolah atau 63,48\% dari 3.657 .353 anak balita. Cakupan tersebut menurun dibandingkan tahun 2009 sebesar 64, 03\% dan masih dibawah target $80 \%$, hal ini perlu diperbaiki apabila terjadi permasalahan pertumbuhan dan perkembangan (Dinas Kesehatan Provinsi Jawa Timur, 2011). Prevalensi masalah perkembangan psikososial seperti gangguan emosional sebesar 10\% dan gangguan tingkah laku pada anak sebesar 19\% (Polaha et al, 2011).

PAUD sebagai lembaga pendidikan dapat menyelenggarakan deteksi dini pertumbuhan dan perkembangan serta pemberian stimulasi perkembangan. PAUD yang berada di Kabupaten Kediri merupakan kelompok yang akan dijadikan mitra pada kegiatan pengabdian kepada masyarakat. Kerjasama akan dibentuk dalam upaya untuk membina guru PAUD dalam meningkatkan pengetahuan dan keterampilan untuk mendeteksi pertumbuhan dan perkembangan dengan menggunakan alat ukur yang tepat serta memberikan stimulasi perkembangan sesuai dengan tahapan usia anak. Hal ini dirasakan perlu berdasarkan permasalahan pertumbuhan dan perkembangan yang terjadi anak balita atau prasekolah. Berdasarkan latar belakang ini, Dosen Pembimbing Lapangan Kuliah Kerja Nyata Belajar Bersama Masyarakat Universitas Airlangga berkeinginan untuk melakukan kegiatan pengabdian kepada masyarakat tentang pemberdayaan PAUD sebagai upaya peningkatan tumbuh kembang anak.

\section{METODE PELAKSANAAN}

Kegiatan ini telah dilaksanakan mulai tanggal 20 Juli-31 Oktober 2017 di Desa Petok, Kecamatan Mojo, Kabupaten Kediri yang diikuti oleh 16 orang guru PAUD dan kader posyandu, dengan metode sebagai berikut: 


\subsection{Analisa Komunitas}

Tahap ini dilakukan untuk mencari informasi terkait permasalahan berdasarkan fakta dan informasi yang terjadi di wilayah Kuliah Kerja Nyata (KKN).

\subsection{Persiapan Materi dan Media}

Tahapan yang dilakukan adalan menyusun kurikulum/ silabus, silabus disusun berdasarkan rangkaian program dengan indikator keberhasilan dan tujuan yang akan dicapai selama proses pelaksanaan yang meliputi kognitif, afektif dan psikomotor. Kemudian tim menyusun modul yang digunakan pada kegiatan pelatihan. Buku panduan atau modul berisi materi tumbuh kembang anak, deteksi perkembangan anak, stimulasi perkembangan dan alat permainan edukasi. Untuk deteksi perkembangkan yang dikenalkan kepada mitra adalah Kuesioner Pra Skrining Perkembangan (KPSP). Selain itu dilakukan pengadaan alat penunjang yang berupa kit skrining perkembangan, lembar KPSP dan alat permainan edukasi berdasarkan usia anak

\subsection{Pelaksanaan Kegiatan}

Pelaksanaan program pengabdian kepada masyarakat dimulai dengan melakukan sosialisasi program. Sosialisasi dilakukan ke Kepala Desa Petok, Kecamatan Mojo, Kabupaten Kediri yang bertujuan untuk memperkenalkan program dan tujuannya. Kemudian dilanjutkan dengan pelaksanaan program, kegiatan dimulai dengan pre test untuk mengetahui tingkat pengetahuan mitra sebelum diberikan pelatihan. Kemudian dilanjutkan dengan pelatihan deteksi perkembangan anak. Pemberian materi kepada mitra tentang pertumbuhan dan perkembangan anak, deteksi perkembangan anak, stimulasi perkembangan dan alat permainan edukatif. Pelatihan ini disampaikan oleh tim pengmas yang memiliki keahlian di bidang keperawatan anak. Kegiatan ini dilanjutkan dengan praktik skrining perkembangan dan dilakukan pendampingan oleh tim pengmas.

\subsection{Evaluasi}

Evaluasi program pengabdian kepada masyarakat dengan melakukan post test. Post test dilakukan setelah penyampaian materi dengan tujuan untuk mengetahui perubahan tingkat pengetahuan mitra. Selain itu dilakukan monitoring dengan pemantauan terhadap keterampilan mitra dalam melakukan skrinning perkembangan, membuat jadwal rutin untuk skrining perkembangan dan menjalankan program secara teratur untuk melakukan skrinning kepada anak usia dini.

\section{HASIL DAN PEMBAHASAN}

\subsection{Hasil}

Program yang dilakukan dalam pengabdian kepada masyarakat ini terdiri dari beberapa tahap. Tahap pertama adalah sosialisasi dan diskusi untuk menjelaskan kepada kepala desa dan guru PAUD serta kader posyandu sebagai mitra. Keterlibatan kader posyandu disebabkan guru PAUD sebagian berlatar belakang kader posyandu.

Tahap kedua pelatihan pada tanggal 5 Agustus 2017, masyarakat mitra diberikan materi tentang konsep pertumbuhan dan perkembangan anak, deteksi perkembangan, stimulasi perkembangan dan alat permainan edukatif. Kegiatan ini dihadiri oleh 16 orang guru PAUD dan kader Posyandu. Kegiatan ini dimulai dengan pre tes untuk mengetahui tingkat pengetahuan sebelum diberi materi. Setelah diberikan materi, mitra diberikan pelatihan berupa praktik untuk melakukan skrining perkembangan pada anak. Mitra dibekali dengan modul, alat skrining perkembangan dan alat tulis. 
Tahap ketiga untuk meningkatkan keterampilan sasaran dalam melakukan skrinning perkembangan, maka dilakukan pendampingan untuk melakukan penilaian perkembangan kepada peserta didik dengan monitor dari tim pengmas dan mahasiswa KKN. Mitra juga diajarkan untuk membuat jadwal skrinning perkembangan secara teratur setiap 3 bulan sekali dan melakukan pengklasifikasian terhadap alat permainan edukatif berdasarkan tahap usia. Monitoring dilakukan dengan melihat hasil skrinning perkembangan dan kemampuan mitra dalam melakukan klasifikasi alat permainan.

\subsection{Pembahasan}

Tahap evaluasi untuk pengetahuan sasaran berdasarkan nilai pre test dan post test. Hasil didapatkan terjadi peningkatan pengetahuan

Tabel 3.1 Distribusi Pengetahuan Mitra

\begin{tabular}{|l|l|c|c|c|c|}
\hline \multirow{2}{*}{ No } & Tingkat pengetahuan & \multicolumn{2}{|c|}{ Pre test (n=16) } & \multicolumn{2}{c|}{ Post test (n=16) } \\
\cline { 3 - 6 } & & $\mathbf{n}$ & $\mathbf{\%}$ & $\mathbf{n}$ & $\mathbf{\%}$ \\
\hline \multirow{4}{*}{1} & Pertumbuhan dan perkembangan & & & & \\
\cline { 2 - 6 } & Baik & 11 & 68,75 & 15 & 93,75 \\
\cline { 2 - 6 } & Cukup & 4 & 25,00 & 1 & 6,25 \\
\cline { 2 - 6 } & Kurang & 1 & 6,25 & 0 & 0 \\
\hline \multirow{4}{*}{2} & Deteksi perkembangan & & & & \\
\cline { 2 - 6 } & Baik & 10 & 62,5 & 11 & 68,75 \\
\cline { 2 - 6 } & Cukup & 4 & 25,0 & 0 & 31,25 \\
\cline { 2 - 6 } & Kurang & & & & \\
\hline 3 & Alat permainan edukatif & 0 & 0 & 10 & 62,5 \\
\cline { 2 - 6 } & Baik & 10 & 62,5 & 5 & 31,25 \\
\cline { 2 - 6 } & Cukup & 6 & 37,5 & 1 & 6,25 \\
\cline { 2 - 6 } & Kurang & & & & \\
\hline
\end{tabular}

Berdasarkan tabel 3.1 pengetahuan pertumbuhan dan perkembangan anak meningkat untuk kategori baik menjadi 93,75\%, pengetahuan deteksi perkembangan untuk kategori baik sebesar $68,75 \%$ dan pengetahuan alat permainan edukatif pada kategori baik sebesar 62,5\%. Secara keseluruhan terjadi peningkatan pengetahuan mitra. Oleh sebab itu program ini meningkatkan pengetahuan masyarakat mitra. Selain itu terjadi peningkatan keterampilan untuk melakukan skrining perkembangan dan kemampuan untuk mengklasifikasian alat permainan edukatif yang menunjang pertumbuhan dan perkembangan anak.

Monitoring dan controlling untuk praktik skrinning dilakukan dengan melakukan kunjungan ke mitra untuk mengetahui perkembangan kemandirian dalam melakukan skrinning perkembangan dan kendala yang dihadapi.

Potensi keberlanjutan program ini guru PAUD yang telah terlatih dapat melakukan membagikan pengetahuan dan keterampilan yang telah dimiliki kepada orang tua murid. Selain itu guru PAUD memiliki kemampuan tidak hanya dalam pengajaran namun juga memperhatihan pertumbuhan dan perkembangan anak didik mereka.

\section{KESIMPULAN DAN SARAN}

\subsection{Kesimpulan}

1. Pengetahuan mitra tentang pertumbuhan dan perkembangan anak, deteksi perkembangan dan alat permainan edukatif meningkat 
2. Mitra dapat melakukan skrining perkembangan dengan KPSP

3. Tersusun jadwal rutin dari PAUD untuk melakukan skrining perkembangan terhadap anak didiknya

4. Mitra dapat menyusun alat permainan edukatif sesuai dengan klasifikasinya

\subsection{Saran}

Program pengabdian kepada masyarakat ini dapat dilanjutkan bersama dengan orang tua yang memiliki anak usia dini sebagai mitra. Dukungan dari Kepala Desa sangat menunjang proses keberlanjutan program sebagai upaya preventif untuk mencegah masalah pertumbuhan dan perkembangan pada anak.

\section{UCAPAN TERIMAKASIH}

Terima kasih kepada Prof. Dr. Mohammad Nasih, SE., Mt., CMA selaku Rektor Universitas Airlangga, Ketua LP4M UNAIR Prof. Dr. H. Jusuf Irianto, M.Com, Dekan Fakultas Keperawatan UNAIR Prof. Dr. Nursalam, M.Nurs (Hons), Kepala Desa Petok beserta guru PAUD dan kader posyandu yang telah bersedia menjadi mitra kami dan semua pihak yang terlibat dalam terlaksananya kegiatan pengabdian kepada masyarakat.

\section{DAFTAR PUSTAKA}

Hockenberry, M.J., and Wilson, D (2009). Essentials of Pediatric Nursing. Mosby Hockenberry, M \& Wilson, D. (2012). Wong's Essentials of Pediatric Nursing (9th Ed.). Elsevier Inc.

Kemenkes RI. (2010). Pedoman kader seri kesehatan anak. Jakarta: Direktorat Bina Kemenkes (2016). Situasi Balita Pendek. Infodatin

Polaha, J. Dalton,W. and Allen, S (2011). The Prevalence of Emotional and Behaviour Problems in Pediatric Primary Care Serving Rural Children. Journal of Pediatric Psychology.36(6):652-660

Suyanto, S (2005). Dasar-dasar Pendidikan Anak Usia Dini. Yogyakarta. Hikayat Publishing

Unicef (2013). The formative years: UNICEF's work on measuring early childhood development. Diperoleh dari https://data.uni cef.org/resources/the-formative-years-unicefs-work-on-measuring-ecd/

Utami, dkk (2013). Pendidikan Anak Usia Dini. Konsorsium Sertifikasi Guru. 